\title{
Neuroprotective Activity of Garcinia pedunculata Roxb. ex Buch.-Ham. Fruit Extract Against Aluminium Chloride Induced Neurotoxicity in Mice
}

\author{
Ravi Mundugaru1, Sunil Kumar Koppala Narayana ${ }^{2}$, Shrinidhi R Ballal ${ }^{3}$, Jacob Thomas ${ }^{4^{*}}$, \\ Rajakrishnan $\mathbf{R}^{4}$
}

${ }^{1}$ Department of Pharmacology and Toxicology, SDM Centre for Research in Ayurveda and Allied Sciences, Kuthpady, UDUPI. ${ }^{2}$ Department of Pharmacognosy, SDM Centre for Research in Ayurveda and Allied Sciences, Kuthpady, UDUPI.

${ }^{3}$ Department of Agada Tantra, SDM College of Ayurveda, Kuthpady, UDUPI.

${ }^{4}$ Department of Botany \& Microbiology, College of Science, King Saud University, P.O. Box 2455, Riyadh 11451, SAUDI ARABIA.

\begin{abstract}
Aluminium chloride $\left(\mathrm{AlCl}_{3}\right)$ is a known potent environmental neurotoxin causing progressive neurodegenerative changes in brain. The present study was aimed to evaluate the neuroprotective activity of aqueous extract of fruit rind of Garcinia pedunculata on chronic exposure of aluminium chloride induced neurotoxicity in Swiss albino mice. Albino mice were categorized into four different groups; Group 1-served as vehicle control, Group 2 mice were administered with $\mathrm{AlCl}_{3} 40 \mathrm{mg} / \mathrm{kg}$ body weight i.p. for 45 consecutive days. Groups 3 \& 4 mice were administered with $\mathrm{AlCl}_{3} 40 \mathrm{mg} / \mathrm{kg}$ body weight i.p. for 45 consecutive days along with aqueous extract of fruits of $G$. pedunculata $200 \& 400 \mathrm{mg} / \mathrm{kg}$ body weight. Chronic administration of $\mathrm{AlCl}_{3}$ developed behavioral deficits, triggered lipid peroxidation and AChE activity and reduced levels of catalase, glutathione peroxidase and histological aberrations. Co administration of aqueous extract of $G$. pedunculata has attenuated the $\mathrm{AlCl}_{3}$ induced alteration in the behavioral, lipid peroxidation, catalase, glutathione peroxidase, AChE and histological changes of brain tissue. Thus the results of the present study have demonstrated the protective role of aqueous extract of fruit rind of $G$. pedunculata against $\mathrm{AICl}_{3}$ induced neurotoxicity.
\end{abstract}

Key words: Acetylcholine esterase, Aluminium chloride, Garcinia pedunculata, Lipid peroxidation, Neurotoxicity.

\section{INTRODUCTION}

Aluminium chloride has been considered as an environmental factor that contributes neurodegenerative disorders. Aluminium particularly interact with enzymes and biomarkers related to Alzheimer's disease. ${ }^{1}$ Occupational exposure of Aluminium can occur through diet by food processing \& storage in aluminium vessels, cans and foil, drinking water, medicines such as antacids, vaccines and cosmetic agents etc. It has been reported that an average dietary intake of aluminium ranges from $3-12 \mathrm{mg} /$ day. The population who are routinely exposed to the product may have higher chances of neurotoxicity. ${ }^{2,3}$ The repeated exposure of aluminium can cause severe oxidative stress and pathological alteration. Aluminium acts as a pro oxidant and on continuous exposure starts accumulation in cortex, hypothalamus and different parts of brain, where it induces the formation of reactive oxygen species (ROS) and result in oxidative damage. ${ }^{4}$ Aluminium also promotes amyloidosis $\beta$ peptide formation and amyloidosis which leads to Alzheimer's disease. Increased accumulation of $\mathrm{AlCl}_{3}$ in brain will affect the slow and
Submission Date : 06-04-2016 Revision Date : 12-05-2016 Accepted Date : :20-05-2016

DOI: 10.5530/ijper.50.3.17 Correspondence: Jacob Thomas,

Department of Botany \& Microbiology, College of Science, King Saud University, P.O. Box 2455, Riyadh 11451, SAUDI ARABIA. Email: jathomas@ksu.edu.sa; rrajagopal@ksu.edu.sa

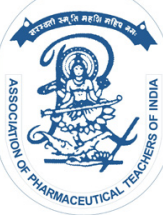

www.ijper.org 
fast axonal transports and cause neuro-inflammation and synoptic structural abnormality resulting in neurodegeneration. Aluminium mainly causes degeneration of cholinergic nerve terminals in cortical areas and cell depletion leads to severe learning deficits. ${ }^{5}$

Plants are considered as the great reservoir of structurally diverse molecules with therapeutic values and are useful in the treatment of various ailments. The fruits of Garinia pedunculata belonging to family Clusiaceae are commonly known as 'Amlavethasa'. The pericarps of the fruits are extensively used in diet across the north eastern states of India. It has the following folklore claims such as rejuvenator, cardio tonic, asthma, obesity and arthritis. ${ }^{6,7}$ Phytochemical analysison their dried fruit rinds has confirmed the presence of (-) hydroxyl citric acid, benzophenones, pedunculol, garcinol and combogenn. ${ }^{8}$ The pharmacological studies have shown that the aqueous extract of the fruit rinds possesses anti-inflammatory, ${ }^{9}$ hepatoprotective, ${ }^{10}$ cardio-protective and in vitro antioxidant activities. ${ }^{11}$ The test drug has strong anti-inflammatory, anti-oxidant and cytoprotective properties and hence the present study was aimed to screen the neuro protective activity of the aqueous extract of dried fruit rinds of $G$. pedunculata against aluminium chloride induced neurotoxicity.

\section{MATERIALS \& METHODS}

\section{Chemicals}

Aluminum chloride hexahydrate $\left(\mathrm{AlCl}_{3} \cdot 6 \mathrm{H}_{2} \mathrm{O}\right)$ (Thomas Baker Pvt. Chemicals Mumbai, India.) and all other chemicals and reagents used were of analytical grade.

\section{Plant material and extract preparation:}

Fruits of G. pedunculata were procured from Assam during April 2015, authenticated in Pharmacognosy laboratory at SDM Research Centre, Udupi, shade dried and powdered at SDM Pharmacy Udupi. $500 \mathrm{~g}$ was soaked in $2 \mathrm{~L}$ of cold distilled water for $24 \mathrm{~h}$, filtered and concentrated by evaporation on water bath until free from water.

\section{Experimental animals}

Swiss albino mice of either sex, (30 to $40 \mathrm{~g}$ body weight) were obtained from animal house attached to the department of Pharmacology \& Toxicology of SDM Centre for research in Ayurveda and Allied Sciences Udupi, India (temperature at 25 to $27^{\circ} \mathrm{C}$, humidity of 50 to $55 \%$ and $12 \mathrm{~h}$ light and dark cycles). Animals were fed with commercial pellet diet and water ad libitum. Approval for the experimental protocol used for this study was made by the institutional animal ethical committee (No. is SDMCRA/IAEC/SDM-03/25/08/2015).

Acute oral toxicity test: It was carried out as per OECD guidelines 425, using AOT software. The aqueous extract of fruit rinds of $G$. pedunculata (AFGP) was made into a suspension in $0.5 \%$ Carboxy methyl cellulose and dosed in the following order 175, 550, and $2000 \mathrm{mg} / \mathrm{kg}$ body weight. The animals were observed for 14 days for mortality. The $\mathrm{LD}_{50}$ was determined by AOT 425 statpgm software.

Experimental design: Group 1 mice were treated with $0.5 \%$ Carboxy methyl cellulose orally for 45 consecutive days and considered as vehicle control. Group $2\left(\mathrm{AlCl}_{3}\right.$ control) were treated with $40 \mathrm{mg} / \mathrm{kg} \mathrm{AlCl}{ }_{3}$ (pH 7) intraperitoneal for 45 consecutive days. Group 3 \& 4 rats were co-administered with aqueous extract of dried fruit rinds of G. pedunculata (AFGP) $200 \& 400 \mathrm{mg} / \mathrm{kg}$ body weight respectively an hour before $\mathrm{AlCl}_{3}$ administration for 45 consecutive days. At the end of the experimental period mice were sacrificed by decapitation and sera and brain tissues were collected from each group. The brain tissues were immediately homogenized, centrifuged and the supernatant was stored at $-20^{\circ} \mathrm{C}$ for $72 \mathrm{~h}$ and further used for biochemical analysis.

\section{Behavioral assessment}

Tail suspension test: The total duration of immobility induced by tail suspension was measured according to a standard method. ${ }^{12}$ Mice isolated both acoustically and visually, were suspended $50 \mathrm{~cm}$ above the floor by adhesive tape placed approximately $1 \mathrm{~cm}$ from the tip of the tail. Immobility time was recorded during a 6 min test. ${ }^{12}$

Forced Swimming Test: An hour after the last dose of group specific drugs, individual mouse was put into a water filled $(30 \mathrm{~cm})$ glass cylinder measuring about $40 \mathrm{~cm} \times 18 \mathrm{~cm}$ and observations were made for 6 minutes. First two minutes were not considered for recording the drug effect and were taken as stabilizing time. The limb movements and the effort of the mice to get out of the cylinder in the next 4 minutes was noted and subtracted later from total time $(4 \mathrm{~min})$ to find the time of immobility. This was considered as the index of depression. ${ }^{13}$

Preparation of brain homogenate: Brain was excised and cleaned with ice cold saline and stored in $-20^{\circ} \mathrm{C}$ in freezer. Tissues were thawed and homogenized in phosphate buffer saline $\mathrm{pH} 7.4$, centrifuged at $4^{\circ} \mathrm{C}$ and supernatant stored at $-20^{\circ} \mathrm{C}$. The homogenate was subjected to determination of catalase activity, glutathione peroxidase activity and lipid peroxidation.

Determination of catalase activity: $1 \mathrm{ml}$ of brain tissue homogenate was mixed with $5 \mathrm{ml}$ of phosphate buffer and $4 \mathrm{ml}$ of $0.2 \mathrm{M} \mathrm{H}_{2} \mathrm{O}_{2}$ in phosphate buffer and time 
was noted. Exactly after 180 seconds of adding $\mathrm{H}_{2} \mathrm{O}_{2}$, a set of $1 \mathrm{ml}$ of reaction mixture from the above was taken in $2 \mathrm{ml}$ dichromate acetic acid. It was kept in boiling water bath for 10 minutes, cooled all the tubes under running tap water and finally noted the reading at $570 \mathrm{~nm}$ against reagent blank. Catalase activity in the tissue was expressed as $\mu$ moles $\mathrm{H}_{2} \mathrm{O}_{2}$ consumed / $\mathrm{mg}$ protein / $\mathrm{min} .^{14}$ Determination of lipid peroxidation: Lipid peroxidation activity was determined by measuring the content of the Thio-barbituric acid reactive substances (TBARs).$^{15}$ Level of lipid peroxidation was expressed as mmoles of MDA formed/g wet tissue.

Determination of Glutathione peroxidase: Glutathione peroxidase was estimated by using a standard protocol ${ }^{16}$ and the glutathione peroxidase activity was expressed as $\mu$ molar glutathione utilized per $\mathrm{mg}$ protein per minute at $37^{\circ} \mathrm{C}$.

Histopathology of brain: Five brain samples from each group were used and ten slices per sample were examined for histopathalogical study. Immediately after the excision from mice, the brain tissue was transferred into $10 \%$ formalin. Sections of less than $5 \mu \mathrm{m}$ thickness of brain tissue were prepared using microtome and stained with haematoxyline and eosin for microscopic observations. ${ }^{17}$ All slides were then evaluated under light microscope (ZEISS Axio lab A1 India).

Statistical analysis: The obtained data were expressed as Mean \pm SEM and analyzed by one way ANOVA, followed by Dunnet's multiple comparison ' $\mathrm{t}$ ' test using Graph Pad Prism 3. A p $<0.05$ were considered as statistically significant.

\section{RESULTS}

Acute oral toxicity study did not reveal any mortality in any dose up to $2,000 \mathrm{mg} / \mathrm{kg}$ of aqueous extract of fruits of the plant $G$. pedunculata. This indicates that $\mathrm{LD}_{50}$ is much more than $2,000 \mathrm{mg} / \mathrm{kg}$ and hence $1 / 10^{\text {th }}$ and $1 / 5^{\text {th }}$ of the higher dose studied $(200 \mathrm{mg} / \mathrm{kg})$ dose was selected for the present neuro protective study.

Effect of AFGP on $\mathrm{AlCl}_{3}$-induced behavioral changes in mice: In the tail suspension test, the duration of immobility time was significantly increased in $\mathrm{AlCl}_{3}$ control as compared to vehicle control, whereas the co-administration of AFGP at both dose levels attenuated the immobility time but at higher dose level, observed significant reduction in immobility time as compared to $\mathrm{AlCl}_{3}$ control $(\mathrm{p}<0.05)$ (Table 1).

In Behavioral despair test, the duration of freezing time was significantly increased in $\mathrm{AlCl}_{3}$ administered group as comparison to vehicle control $(\mathrm{p}<0.01)$. Co administration of $\mathrm{AlCl}_{3}$ has significantly attenuated the freezing time in both the dose levels of AFGP as compared to $\mathrm{AlCl}_{3}$ control $(\mathrm{p}<0.01)$ (Table 2$)$.

Effect of AFGP on AChE: AChE is a key enzyme involved in cholinergic neurotransmission and is a marker of extensive loss of cholinergic neurons in the brain. A significant increase $(\mathrm{P}<0.01)$ in the level of $\mathrm{AChE}$ was observed in the animals induced with $\mathrm{AlCl}_{3}$. AFGP co administered with $\mathrm{AlCl}_{3}$ attenuated $\mathrm{AChE}$ levels; however the observed decrease was non-significant in comparison to $\mathrm{AlCl}_{3}$ control group (Table 3).

Effect of AFGP on antioxidant parameters: Aluminium chloride induced free radical mediated oxidative cell injury is one of the important manifestations to elevated lipid peroxidation. In the present study there is an increased lipid peroxidation in the Aluminium chloride administered group as compared to vehicle control $(\mathrm{p}<0.01)$. The $\mathrm{AlCl}_{3}$ induced lipid peroxidation was significantly attenuated by co-administration of AFGP $(\mathrm{p}<0.01)$. Repeated administration of $\mathrm{AlCl}_{3}$ caused marked oxidative stress, which led to decrease in the antioxidant enzymes activities such as catalase and glutathione peroxidase as comparison to control group mice; while AFGP co-administered with $\mathrm{AlCl}_{3}$ has increased the activity of catalase and non-significant changes in glutathione peroxidase as compared to $\mathrm{AlCl}_{3}$ control. (Table 4).

Histopathalogical changes: Chronic administration of aluminum chloride produced moderate intensity of neuro degeneration in different parts of the brain like fore brain, mid brain, hippocampus and cerebellum. In hippocampus, there is a decrease in the pyramidal cells population, cellular disorganization and distorted cells. These changes were significantly attenuated by the administration of AFGP at both the dose levels (Figure 1). In $\mathrm{AlCl}_{3}$ control mice forebrain and mid brain sections have shown edematous changes, cellular disorganization and cell distortion, whereas AFGP administered at higher dose level significantly prevented $\mathrm{AlCl}_{3}$ induced changes (Figures. 2 and 3).

Repeated administration of $\mathrm{AlCl}_{3}$ has caused micro cytic changes in the cellular layer of cerebellum and these changes were attenuated by AFGP administered at both the dose level (Figure 4).

\section{DISCUSSION}

Aluminium on repeated exposure is experimentally documented neurotoxin and able to cross the blood brain barrier. It is implicated in the pathological changes in Alzheimer's disease and other neurodegenerative disorders. It is considered as an important environmental factor to wide range of neurodegenerative disorders. ${ }^{18}$ 
Table 1: Effect of aqueous extract of fruits of Garcinia pedunculata (AFGP) in Tail suspension test

\begin{tabular}{|c|c|}
\hline Groups & Duration of immobility time (sec) \\
\hline Vehicle control & $49.8 \pm 6.16$ \\
\hline $\mathrm{AlCl}_{3}$ Control & $157.25 \pm 38.095^{*}$ \\
\hline $\mathrm{AEGP} 200 \mathrm{mg} / \mathrm{kg}+\mathrm{AlCl}_{3}$ & $74.2 \pm 22.33$ \\
\hline $\mathrm{AEGP} 400 \mathrm{mg} / \mathrm{kg}+\mathrm{AlCl}_{3}$ & $39 \pm 22.19^{\#}$ \\
\hline
\end{tabular}

Data expressed as Mean $\pm \mathrm{SEM}, * \mathrm{P}<0.05$ in comparison to normal control group, ${ }^{*} \mathrm{p}<0.05$ in comparison to $\mathrm{AlCl}_{3}$ control.

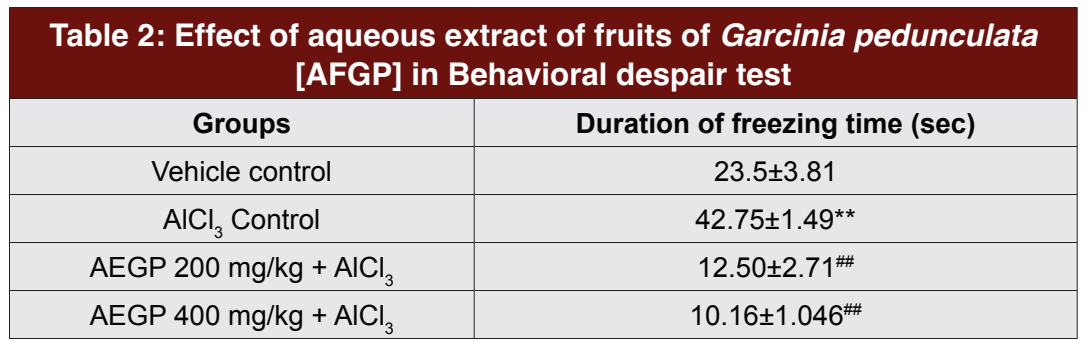

Data expressed as Mean $\pm \mathrm{SEM}, * * \mathrm{P}<0.01$ in comparison to normal control group, ${ }^{\# \#} \mathrm{p}<0.01$ in comparison to $\mathrm{AlCl}_{3}$ control.

\section{Table 3: Effect of aqueous extract of fruits of Garcinia pedunculata} [AFGP] on serum Acetylcholine esterase

\begin{tabular}{|c|c|}
\hline Groups & Acetylcholine esterase [IU/L] \\
\hline Vehicle control & $3813.3 \pm 168.16$ \\
\hline $\mathrm{AlCl}_{3}$ Control & $5081.9 \pm 270.56$ ** \\
\hline $\mathrm{AEGP} 200 \mathrm{mg} / \mathrm{kg}+\mathrm{AlCl}_{3}$ & $4898.32 \pm 163.05$ \\
\hline $\mathrm{AEGP} 400 \mathrm{mg} / \mathrm{kg}+\mathrm{AlCl}_{3}$ & $4405.3 \pm 278.17$ \\
\hline
\end{tabular}

Data expressed as Mean $\pm \mathrm{SEM}, * * \mathrm{P}<0.01$ in comparison to normal control group.

\begin{tabular}{|c|c|c|c|}
\hline Groups & $\begin{array}{c}\text { Catalase } \\
\text { ( } \mu \mathrm{moles} / \mathrm{min} / \mathrm{mg} \text { protein) }\end{array}$ & $\begin{array}{c}\text { Glutathione peroxidase } \\
\text { ( } \mu \text { moles glutathione } / \mathrm{mg} \\
\text { protein for } 10 \mathrm{~min} \text { ) }\end{array}$ & $\begin{array}{l}\text { Lipid peroxidation (mmoles } \\
\text { of MDA formed /g wet tissue) }\end{array}$ \\
\hline Vehicle control & $6996.96 \pm 1078.1$ & $3522.7 \pm 6.39$ & $25.7621 \pm 318.28$ \\
\hline $\mathrm{AlCl}_{3}$ Control & $1373.31 \pm 10.73^{* *}$ & $2325.92 \pm 788.18$ & $404.165 \pm 39.86^{* *}$ \\
\hline $\mathrm{AEGP} 200 \mathrm{mg} / \mathrm{kg}+\mathrm{AlCl}_{3}$ & $3082.75 \pm 823.75$ & $1321.49 \pm 277.68$ & $65.64 \pm 33.50^{\# \#}$ \\
\hline $\mathrm{AEGP} 400 \mathrm{mg} / \mathrm{kg}+\mathrm{AlCl}_{3}$ & $2496.70 \pm 308.68$ & $1267.32 \pm 444.8$ & $53.81 \pm 18.67^{\# \#}$ \\
\hline
\end{tabular}

Data expressed as Mean $\pm \mathrm{SEM}, * * \mathrm{P}<0.01$ in comparison to normal control group, ${ }^{\# \#} \mathrm{p}<0.01$ in comparison to $\mathrm{AlCl}_{3}$ control.

Correlation between $\mathrm{AlCl}_{3}$ accumulation and progressive oxidative damage on the brain tissues have been already reported, it can induce lipid peroxidation and alter physiological and biochemical characteristics of biological system. ${ }^{19}$ Several natural products such as curcumin, quercetin, naringin and catechins have potential neuroprotective activities against $\mathrm{AlCl}_{3}$ induced neurotoxicity. ${ }^{20,21}$ The fruit rinds of Garcinia pedunculata contains (-) hydroxyl citric acid, benzopheneones, pedunculol, garcinol and combogennphyto-constituents and major contributors to the antioxidant activity of $G$. pedunculata. ${ }^{22}$

Current findings have shown that chronic administration of $\mathrm{AlCl}_{3}$ leads to increased levels of lipid peroxidation due to elevated concentration of MDA and decreased catalase and glutathione peroxidase anti-oxidant enzymes in the $\mathrm{AlCl}_{3}$ administered control group.

From the earlier studies it has been documented that the $\mathrm{AlCl}_{3}$ has no direct effect on lipid peroxidation. On repeated exposure it gets accumulated in the brain cells and accelerates iron mediated oxidative stress and cellular damage in acidic and neutral environment leading to neurotoxicity. ${ }^{23}$

Normally brain cells have nonenzymatic and enzymatic mediators to counteract reactive oxygen species mediated oxidative stress. Nonenzymatic molecules are glutathione, thioredoxine and thiol containing molecules, whereas 


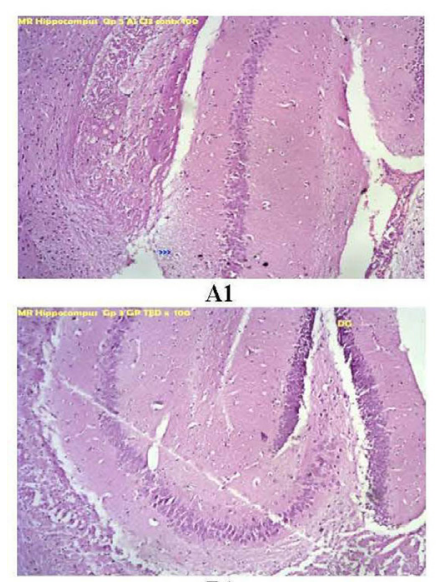

B1

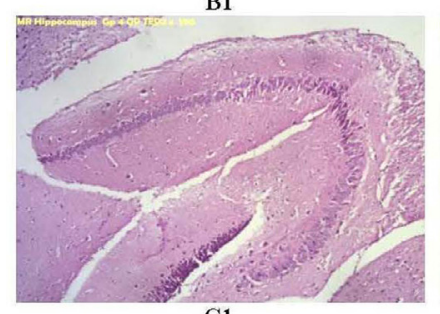

C1

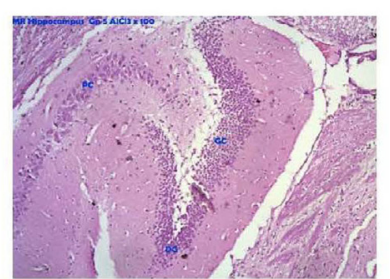

A2

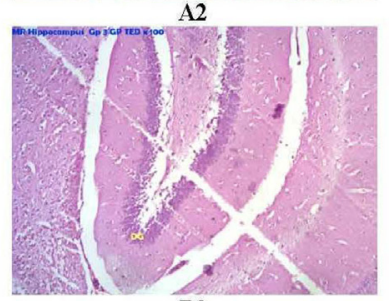

B2

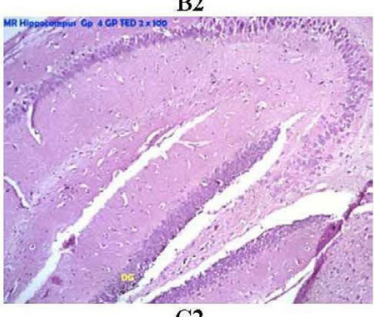

$\mathrm{C} 2$
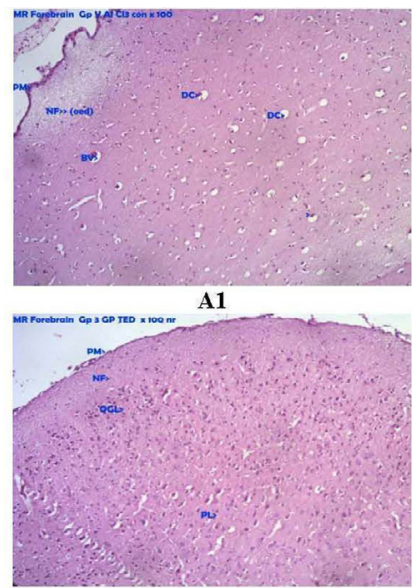

B1

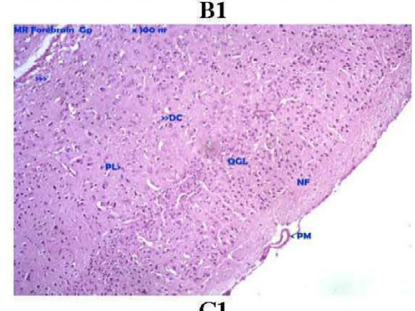

C1

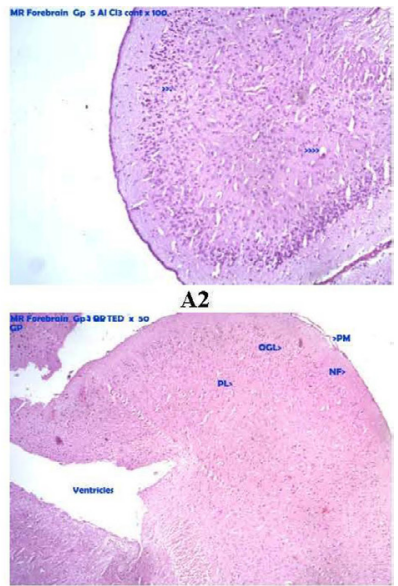

B2

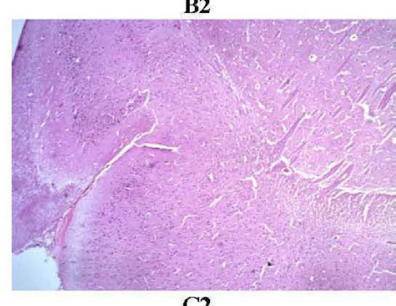

$\mathrm{C} 2$

Figure 1: Photomicrograph of representative brain sections focused on hippocampus region of $\mathrm{AICl}_{3}$ control group (A1\& A2), Test group AFGP administered $200 \mathrm{mg} / \mathrm{kg} \& 400 \mathrm{mg} / \mathrm{kg}$ body weight $+\mathrm{AlCl}_{3}$ (B1\& B2, C1\& C2). $\mathrm{AlCl}_{3}$ administered group rats has shown decrease in the pyramidal cells population, cellular disorganization and distorted cells. These changes were significantly reversed by the administration of AGP at both the dose level. DC- dentate gyrus, PC- pyramidal cells.

enzyme mediators include superoxide dismutase (SOD), catalase (CAT) and glutathione peroxidase (GSH-Px). ${ }^{24}$ SOD is the first defensive enzyme against superoxide and it converts superoxide anions to hydrogen peroxide and oxygen. The generated hydrogen peroxide should be efficiently neutralized by CAT and GSH-Px. Thus these enzymes protect the cells from damaging aggressive hydroxyl radicals. ${ }^{25}$ In the present study there is a significant attenuation of lipid peroxidation and elevated levels of catalase and glutathione peroxidase enzymes in the G. pedunculata co administered with $\mathrm{AlCl}_{3}$ and attenuated the oxidative stress induced by $\mathrm{AlCl}_{3}$.

Acetylcholine esterase is an important enzyme in the cholinergic system involved in the metabolism of acetylcholine neurotransmitter. It has been reported that the increase in the acetylcholine esterase level increased metabolism of acetylcholine leads to oxidative stress causes neurobehavioral changes especially memory and cognitive failure. However, recently it has been shown that circulating $\mathrm{AChE}$ activity reflects inflammatory response, since acetylcholine suppresses inflammation. Based on this premises donepezil an AChE inhibitor is being investigated for neuro protective activity. In the present study significant elevation in serum AChE

Figure 2: Photomicrograph of representative brain sections focused on midbrain region of $\mathrm{AICl}_{3}$ control group (A1 \& A2), AFGP administered $200 \mathrm{mg} / \mathrm{kg} \& 400 \mathrm{mg} / \mathrm{kg}$ body weight + $\mathrm{AlCl}_{3}$ (B1 \& B2, C1\& C2). The Midbrain sections from $\mathrm{AlCl}_{3}$ group shows oedematous changes, cellular disorganization, sparsely cellular light staining areas and cell distortion. The sections from Test-1 group showed mild to moderate oedematous changes, and less cell infiltration in comparison to the control rats. The Test-2 group showed mild to moderate oedematous changes in two rats. Cell infiltration was also found to be less.

activity was observed in aluminium chloride administered group in comparison to the control. This elevation was found to be attenuated in test drug treated groups. This observation can be considered as an additional evidence for the neuroprotective activity indicating the role of $G$. pedunculata in the regulation of cholinergic function. ${ }^{26}$

Repeated administration of $\mathrm{AlCl}_{3}$ has caused microcytic changes in the cellular layer of cerebellum. In forebrain and mid brain sections that there were edematous changes, cellular disorganization and cell distortion in few mice. In hippocampus, there was a decrease in the pyramidal cells population, cellular disorganization and distorted cells. Thus chronic administration of $\mathrm{AlCl}_{3}$ produced moderate intensity of neuro degeneration in different parts of the brain like fore brain, mid brain, hippocampus and changes in cerebellum in few rats. These changes were significantly attenuated by the administration of AFGP at both dose levels. These results demonstrated that the AFGP significantly prevented brain damage and improved functional outcome. 


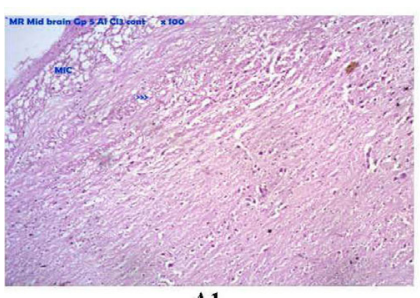

A1
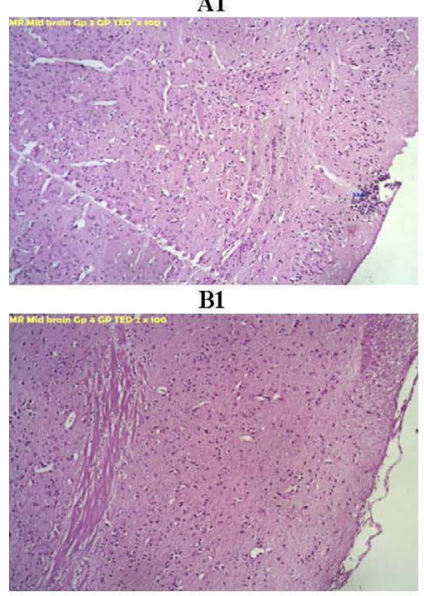

C1

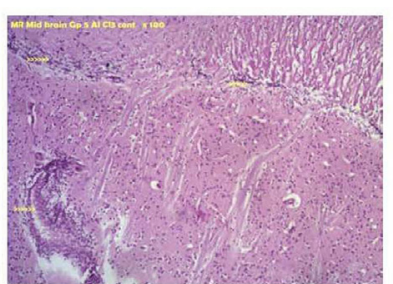

A2

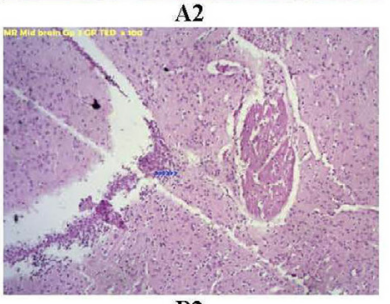

B2

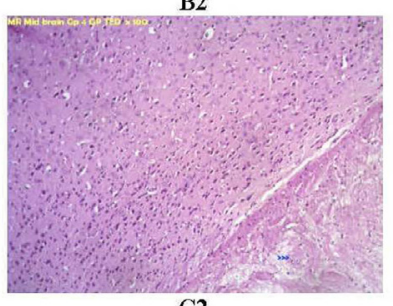

C2

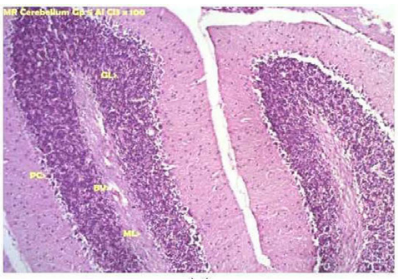

Al

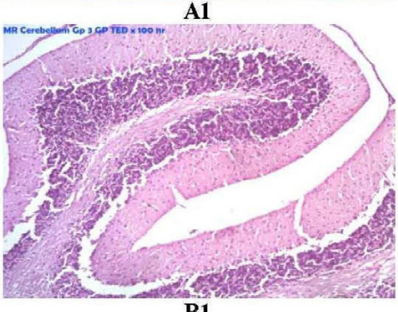

B1

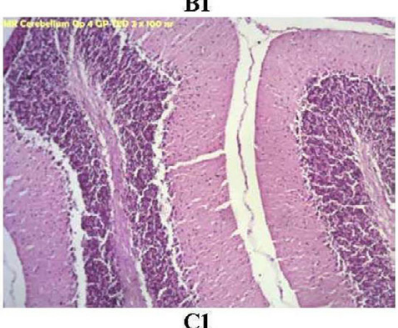

C1

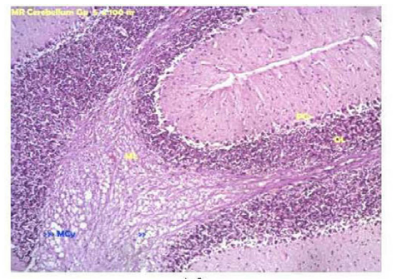

A2

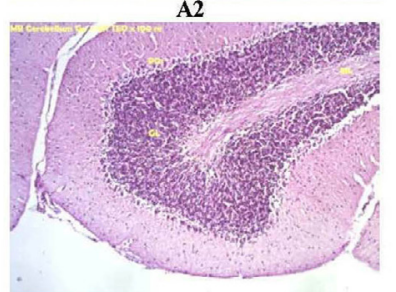

B2

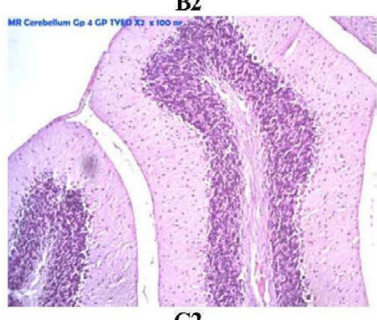

C2

Figure 3: Photomicrograph of representative brain sections focused on forebrain region of $\mathrm{AlCl}_{3}$ control group (A1 \& A2), Test group AFGP administered $200 \mathrm{mg} / \mathrm{kg} \& 400 \mathrm{mg} / \mathrm{kg}$ body weight $+\mathrm{AICl}_{3}$ ( B1 \& B2, C1 \& C2). The forebrain sections from $\mathrm{AlCl}_{3}$ group there was oedematous changes, cellular disorganization and cell distortion in few rats. The sections from test1 and test-2 groups exhibited almost normal cytoarchitecture and few rats showed oedematous changes.

The observed protection by AFGP treatment may be due to its antioxidant and cytoprotective property.

\section{CONCLUSION}

On the basis of the present study it can be concluded that the aqueous extract of Garcinia pedunculata, exhibited significant neuroprotection against $\mathrm{AlCl}_{3}$ induced neurotoxicity in mice according to histological, behavioral and biochemical analysis. The anti-oxidant effect and AChE activity of the test drug may also contribute to the observed neuroprotection.

\section{ACKNOWLEDGEMENT}

The first three authors are grateful to their revered President, Dr. D. Veerendra Heggade for the constant support and Dr. B. Yashoverma, Secretary, SDM Educational Society for the guidance. The last two authors extend their sincere appreciation to the Deanship of Scientific Research at King Saud University for funding this research through Research Group No.: RG-1437-002.

Figure 4: Photomicrograph of representative brain sections focused on cerebellum region of $\mathrm{AICl} 3$ control group (A1 \& A2), Test group AFGP administered $200 \mathrm{mg} / \mathrm{kg} \& 400 \mathrm{mg} / \mathrm{kg}$ body weight $+\mathrm{AlCl}_{3}$ ( B1 \& B2, C1 \& C2). The Cerebellum sections from $\mathrm{AlCl}_{3}$ group exhibited caused microcytic changes in the cellular layer of cerebellum. The sections from test-1 and test-2 groups exhibited normal cytoarchitecture. ML- molecular layer, GL- granular layer, MC- microcytic changes, BV- blood vessels.

\section{CONFLICT OF INTEREST}

There is no conflict of interest from any of our co-authors.

\section{REFERENCES}

1. Yokel RA. Aluminum chelation principles and recent advances. Co-ord. Chem. Rev. 2002;228(2):97-113. http://dx.doi.org/10.1016/S0010-8545(02)00078-4.

2. Ribes D, Colomina MT, Vicens $P$ and Domingo JL. Effects of oral aluminum exposure on behavior and neurogenesis in a transgenic mouse model of Alzheimer's disease. Exp Neurol. 2008;214(2):293-300. http://dx.doi. org/10.1016/j.expneurol.2008.08.017; PMid:18834880.

3. Savory J, Herman MM and Ghribi O. Mechanisms of aluminum induced neurodegeneration in animals: Implications for Alzheimer's disease. J. Alzheimer's Dis. 2006;10(2-3):135-44. PMid:17119283.

4. Cunat L, Lanhers MC, Joyeux M and Burnel D. Bioavailability and intestinal absorption of aluminum in rats: effects of aluminum compounds and some dietary constituents. Biol Trace Elem Res. 2000;76(1):31-55. http://dx.doi. org/10.1385/BTER:76:1:31.

5. Gonzalez MA, Bernal CA, Mahieu S and Carrillo MC. The interactions between the chronic exposure to Aluminum and liver regeneration on bile flow and organic anion transport in rats. Biol Trace Elem Res. 2009;127(2):16476. http://dx.doi.org/10.1007/s12011-008-8234-4 ; PMid:18953510.

6. Jayaprakasha GK, Negi PS and Jena BS. Anti oxidative and anti mutagenic activities of the extracts from the rinds of Garcinia pedunculata. Innovative Food Science \& Emerging Technologies. 2006;7(3):246-50. http://dx.doi. org/10.1016/j.ifset.2006.01.001.

7. Kagyung R, Gajurel PR, Rethy P and Singh B. Ethno medicinal plants used for gastrointestinal diseases by Aditribes of Dehang-Debang Biosphere 
Reserve in Arunachal Pradesh. Indian Journal of Traditional Knowledge. 2010;9(3):496-501.

8. Sahu A, Das B and Chatterjee A. Polyisoprenylatedbenzophenones from Garcinia pedunculata. Phyto chemistry. 1989;28(4):1233-5. http://dx.doi. org/10.1016/0031-9422(89)80216-X.

9. Ravi M, Febin Joy, Shrinidhi R, Lipika Das, Sudhakara and Ravishankar B. Anti-inflammatory activity of aqueous extract of fruits of Garcinia pedunculata in experimental animals. Am J Pharma Tech Research. 2014;4(3):3-6.

10. Ravi M, MadhanChakravarthy and Ravishankar B. Hepatoprotective activity of fruits extract of Garcinia pedunculata. Bangladesh J Pharmacol. 2014;9:48.

11. Ravi M, Senthil Kumar S, Padmaja UK and Sudhakara B. Cardio protective activity of fruits extract of Garcinia pedunculata. Bangladesh J of Pharmacol. 2016;11:5-9.

12. Steru L, Chermat R, Thierry $B$ and Simon P. The tail suspension test: a new method for screening antidepressants in mice. Psychopharmacology. 1985;85(3):367-70. http://dx.doi.org/10.1007/BF00428203; PMid:3923523.

13. Porsolt RD, Bertin A and Jalfre M. Behavioral despair in mice: a primary screening test for antidepressants. Arch Int Pharmacodyn Ther. 1977;229(2):327-36. PMid:596982.

14. Sinha KA. Colorimetric assay of catalase. Anal Biochem.1972;47(2):389-94. http://dx.doi.org/10.1016/0003-2697(72)90132-7.

15. Ohkawa $\mathrm{H}$, Ohishi $\mathrm{N}$ and Yagi K. Assay for lipid peroxides in animal tissues by Thio-barbituric acid reaction. Anal Biochem. 1997;95(2):351-8. http:// dx.doi.org/10.1016/0003-2697(79)90738-3.

16. Rotruck JT, Pope AL, Ganther HE, Swanson AB, Hafeman DG et al. Selenium: biochemical role as a component of glutathione peroxidase. Science. 1973;179(4073):588-90. http://dx.doi.org/10.1126/science.179.4073.588; PMid:4686466.

17. Bancroft JD and Gamble M. Theory and practice of histological techniques. $5^{\text {th }}$ ed. Churchill Livingstone. 2002.

18. Nayak P, Sharma SB and Chowdary NV. Augmentation of aluminum induced oxidative stress in rat cerebrum by presence of pro-oxidant (graded doses of ethanol) exposure. Neurochem Res. 2010;35(11):1681-90. http://dx.doi. org/10.1007/s11064-010-0230-3 ; PMid:20640917.

19. Prakash D, Gopinath K and Sudhandiran G. Fistein enhances behavioral performances and attenuates reactive gliosis and inflammation during aluminum chloride-induced neurotoxicity. Neuromol Med. 2013;15(1):192208. http://dx.doi.org/10.1007/s12017-012-8210-1 ; PMid:23315010.

20. Rios JL, Recio MC, Giner RM and Manez S. An update review of saffron and its active constituents. Phytother Res. 1996;10(3):189-93. http://dx.doi. org/10.1002/(SICl)1099-1573(199605)10:3<189::AID-PTR754>3.0.CO;2-C.

21. Comalada M, Camuesco D, Sierra S, Ballester I. Xaus J, et al. In vivo quercitrin anti-inflammatory effect involves release of quercetin, which inhibits inflammation through down-regulation of the NF-kappa B pathway. Eur J Immunol. 2005;35(2):584-92. http://dx.doi.org/10.1002/eji.200425778; PMid:15668926.

22. Mudoi T, Deka DC and Devi R. In vitro antioxidant activity of Garcinia pedunculata, an indigenous fruit of North Eastern (NE) region of India. International J of Pharm Tech Research. 2012;4(1):334-42.

23. Zafar TA, Teegarden D, Ashendel C, Dunn MA and Weaver CM. Aluminum negatively impacts calcium utilization and bone in calcium- deficient rats. Nutr Res. 2004;24(3):243-59. http://dx.doi.org/10.1016/j.nutres.2003.12.002.

24. Asma B, Ranajoy $C$ and Shankar M. Oxidative stress: An essential factor in the pathogenesis of gastrointestinal mucosal disease. Physiological Review. 2014;94(2):329-54. http://dx.doi.org/10.1152/physrev.00040.2012 ; PMid:24692350:PMCid:PMC4044300.

25. Schrader $M$ and Fahimi HD. Peroxisomes and oxidative stress. Biochim Biophys Acta. 2006;1763(12):1755-66. http://dx.doi.org/10.1016/j. bbamcr.2006.09.006.

26. Noh YH, Baek JY, Jeong W, Rhee SG and Chang TS. Sulfiredoxin Translocation into Mitochondria Plays a Crucial Role in Reducing HyperoxidizedPeroxiredoxin III. J Biol Chem. 2009;284(13):8470-7. http:// dx.doi.org/10.1074/jbc.M808981200; PMid:19176523 PMCid:PMC2659205

\section{SUMMARY}

- The present study was carried out to evaluate the neuroprotective activity of aqueous extract of fruit rind of Garcinia pedunculata Roxb. ex Buch.-Ham.on Aluminium Chloride induced neurotoxicity in Swiss albino mice. Co administration of aqueous extract of $G$. pedunculata has attenuated the $\mathrm{AlCl}_{3}$ induced behavioral, biochemical and histological changes in experimental organisms. 